\title{
Prevotella baroniae
}

National Cancer Institute

\section{Source}

National Cancer Institute. Prevotella baroniae. NCI Thesaurus. Code C124360.

A species of obligately anaerobic, non-motile, Gram-negative coccoid and short bacilli bacteria in the family Prevotellaceae first isolated from the human oral cavity. P. baroniae is able to ferment cellobiose, fructose, glucose, lactose, maltose, mannose, melibiose, raffinose, salicin, and sucrose. 